\title{
The Analysis of Publishing Strategy for Islamic Reference Books in Indonesia
}

\author{
Nur Yudi \\ Library and Information Sciences Department \\ Syarif Hidayatullah State Islamic University Jakarta \\ nuryudi@uinjkt.ac.id
}

\begin{abstract}
Using a qualitative approach, this research aims to reveal the factual phenomenon related to publishing business strategy of Islamic reference books in Indonesia, with a case study in Almahira publisher. The publisher director in Jakarta has been the subject of research to describe the dynamics of its business factors and strategic actions to sustain and cope with the recent challenges. The study emphasizes the use of primary data obtained from in-depth interview and observation, which has been analyzed by using descriptive, interpretative phenomenology and triangulation techniques. The results obtained that the business strategy implemented by the publisher comprises within five integrated actions, those are: direct observation and creative analysis of community needs, enterprise innovations and open mind to competition and diversity, implementing strict pre-print editing procedures, selecting product premium for the segment of upper middle class, and presenting the complete integration of product design concept. With regard to business dynamics, it was known that there has been an increase in the awareness of middle class society for books and reading interest in Islamic studies. In addition, the trend of selling Islamic reference books remains steady and is increasing despite the intense competition and challenges of cultural change of society regarding the use of internet and digital books to obtain information resources.
\end{abstract}

\section{Keywords - Islamic Publishing; Islamic Book} Publishing; Reference Book Publisher; Book Publishing Strategies.

\section{INTRODUCTION}

Strategy is a tool to achieve long-term goals. It is a potential action that requires top management decisions and large amounts of enterprise resources. Strategy is a consistent set of integrated actions in the organization's long-term vision that values customers with a cost structure that is able to achieve sustainable yield excellence. In certain situations, there may be necessary modifications [1]. Boyd \& Walker pointed out that the key issues of the scope of marketing strategy include specifying the target market for a particular product line. So, the companies must seek competitive advantage and synergy through a well- integrated program of marketing mix elements, ... that was designed for the needs and wants of potential customers within the target market [2]. Applying the right marketing strategy can have a positive long-term impact for the company, especially in terms of maintaining customers, controlling existing market share and facing competition. Here, Kotler mentions three aspects that must be considered: segmentation strategy, targeting, and positioning. The company implements a positioning strategy by trying to create the uniqueness of the product by giving a value that can be recorded in the mind of customers, thus forming a value image that is superior to the competitor's product [3]. In addition, developing successful new products requires a systematic planning to coordinate many decisions, activities, and functions necessary to move the new product idea to commercial success. Handito Hadi Joewono asserted that there are eight corporate competition strategies: great perception, quality product, innovative product, customer engagement, massive distribution, competitive price, strive sales person, and customer insight [4].

The phenomenon of Islamic book marketing includes one type of forms, a reference book. The reference book is a book that does not have to be read all, but only part of which is needed. Undeniably the book industry in the country, in recent decades, has grown passionately. This excitement is marked by the emergence of new publishers in various cities in Indonesia and the flood of new books of their products in the market. There is enough attention from the excited industry of the book to the rise of publication of religious books, especially books themed Islam. Agus Musthafa added that the market potential for Islamic business is huge because in this country the majority of Muslims, if touched by the emotional side, that's a good entrance [5]. The fact that Islamic book publishing in Indonesia continues to grow from year to year and the number publisher continues to increase, even though they are faced with the challenge of tight competition and the exploitation of digital information resources.

Does the above social facts have a meaning that the dynamic of Islamic book production, including reference, has been done with respectable business strategy, or a set of reputable integrated actions? If yes, what is the strategy, how are these plans, policies and actions, have been applied to achieve success and advantages? This research seeks to uncover the phenomenon in particular with regard to production approaches of Islamic reference book publishing in which the publisher concerned. With a firm strategy, the publishing companies will be able to gain excellence and a strong product position so that they are always ready in the competition that can be done in a healthy, honest, and open, as recommended in the teachings of Islam.

Therefore, I am interested in conducting a study through research on why and how the phenomenon occurs behind the publication of Islamic reference books, especially in terms of business strategy of Almahira publisher as one of the 
successful companies in answering the challenges in book publishing. I was interested in studying and discussing this because I wanted to know more comprehensive on what and how factors can drive the successful development of Islamic reference publication and how challenges are faced. In one side, the study expected its results to contribute information and knowledge for the approaches and policies needed for such publishers to reach business success and competitive advantages. In other side, together with the government and also information resources agencies, it is expected to improve public literacy equality through the increase of Islamic reference books which are balanced, more qualified and accessible to all levels of Muslim society.

After considering the background related to the publishing business of Islamic reference book mentioned above, I am able to propose the questions or problems discussed in this research: what integrated actions have been consistently implemented by publisher Almahira as strategy to achieve its business success in long term period.

\section{METHOD}

This research used descriptive method with qualitative approach, which is done to obtain factual findings related to various phenomena that arise around the publication of Islamic reference books. The primary data collection technique was conducted purposively with in- depth interview to the subject of the study, Almahira Director. With this method, the researcher can explore not only what is known and experienced by the subject, but also what is hidden deeply within the subject of research, and also includes the things that are cross-time, related to the past, the present, and also the future [6]. Beside that, library research, direc to observation to book stores and analysis of internet electronic files were done to get supporting data for secondary sources and triangulation. The data was analyzed descriptively by looking for interpretive meaning behind the empirical data, based on the main theories used as approaches.

\section{RESULT AND DISCUSSION}

The publishers of Islamic reference books have worked hard in an effort to build image and to get a good perception in front of costumers for every product they have published. To that end, publishers must apply various business strategies so that they retain how their product can still gain profits and appeal in the eyes of customers. Based on the theory of business strategy described by David, and eight competition strategy by Handito Hadi Joewono, and all concepts mentioned above, the study found a series of strategic actions that are empirically practiced by the publisher Almahira. From data presentation, it is known that there are various strategies applied by the publisher to achieve and maintenance the success of its publishing business, those are:

\section{A. Direct Observation and Creative Analysis of Community} Needs.

In order to gain competitive advantages and a commercial success, the publisher must be able to continuously create new creative products based on the three defined policies (segmentation, targeting, and positioning) in order to encourage public interest of having a strong determination in purchasing Islamic reference books. That effort results in the expansion of adequate book distribution as an answer to the lack of books in society. In addition, publishers with new products should also be able to create community learning so that self-motivation arises for the community to have a culture of good growing literacy. To that end, publishers should always compete in capturing market opportunities about the information needs of the people being sought. Among them by doing a direct observation or exploring the needs of community knowledge. In Almahira, for example, when the publisher wanted to determine the title of the husband's behavior, he learned the need for information from mothers regarding the issue of male personality. He found the theme 'Responding Husbands' Behavior '. Not Dealing with the wives' behavior. So, they can publish such reference books which are not available yet in book stores. This kind of book sells good according to Abdul Ghafar [7]. Other books are also very acceptable to the public, as they can be seen from my direct observations in Gramedia bookstore at that time, proved that three titles belong to Almahira were not available (out of stock). Those are: "'Qur'an 7 in one', 'Guidelines for Compre-hensive Prayer' and 'My First Qur'an'. These books successfully maintain reader's perception. This is in line with Ignas Kleden's idea that the insightful publishers are actively shaping the information needs of society within 3 or 5 years. So, they can contribute what they consider essential for cultural development [8]. It was also described byAlfonTaryadi that a creative publisher should combine two types of markets and two types of sales at once: selling books in business and selling them culturally and intellectually [9].

\section{B. To Enterprise Innovations, Be Open to Competition and Diversity}

Almahira is aware of the diversity in the Islamic aspects as an opportunity. The loyalty to accept differences and competition has proven to bring success to the business because there is an opportunity to acquire the idea of enterprise development. Likewise, the publisher is not worried about the increasingly fierce competition. The existence of competition has driven the number of published products and by itself will drive innovations in publishing. The publisher director believes, if people who sell books a lot and crowded, book buyers were so crowded as well. So, the more theyare selling, the more the buyers are. Almahira, emphasizes this motivation especially in an effort to provide a new understanding of Islam through their publishing innovation, as stated that the Muslims society has a diversity of Islamic understandings. There is a hard line, left line, and also right line. So, the director is personally called upon to give way to Muslims to learn what they should know [5]. In this sense, the publisher always tries to innovate with the uniqueness of new products even though the same theme might have already existed. In terms of the innovation effort of Islamic publication, it admitted that the theme of a book that can be practically always tasty, is the theme of religion, children, business opportunities and how to. This is in line with the 
statement presented by Agus Musthafa saying that the market potential is enormous because in this country the major population is Muslims. If being touched by the emotional side, it is a good entrance [10]. Almahira consistently takes the trend and opportunity. Nevertheless, to enterprise innovations for competition advantages, the publisher agreed to keep strong idealism of being moderate, not fanatical or to favor a particular school of thought and not to limit the product to a group of schools of Islam because it would narrow the marketing of the product and not gain public acceptance, instead it would cause society to be fragmented.

\section{To implement a Strict Pre-Print Editing Procedures}

When considered from the vision that become the foundation of the spirit of business activity, Almahira strives to be istiqamah in an effort to maintain the purity of Islamic teachings through the works of publishing. There is also in the spirit of clarifying contrary thoughts in the moderate side standing. To this end, the publisher always implements a strict pre-print editing procedures in order to carefully and safely publish new works for Muslim people within a multi-sects and organization. Thus, a tone that is too loud or contains too heavy material will never be published, nor is the script too light so as to lack of market interest. On the contrary, the difference of ideology and competition has become a blessing opportunity for the development and success of Islamic book publishing business by making new innovations with product modification, for example with the concept of integrative and thorough discussion for meeting the truth. As stated by A. Ghafa, it is important to convey information that has something to do with haqwalbathil which has a meaning to convey a truth, what is right and what is wrong. This publishing activity is believed to be a part of the effort to straighten out deviant views in society, as a part of a mission to purify Islamic teachings by the publishers through Islamic books. For this purpose, Almahira presents publications that conducts a tight editing process based on authentic and reliable sources, such as Tafsir Imam Syafi'i's book. Almahira believe, those who are able to apply istiqomah in aqidah, will succeed. It is acknowledged that one form of purification effort is that one does not favor one mahzab. The alightment of aqidah field is being more emphasized, including avoiding superstition. But on the contrary, the dynamics of differences in thinking is even encouraged, because it can generate the development or innovations. Almahira even encourages khilafiah (differences) on the realm of thought, as long as it is not on the thoughts that injure the al-Qur'an and al-Hadith and not concerning aqidah and worship [11].

\section{Setting Market Segments with Premium Products for Upper Middle Classes}

When asked to Almahira why targeting the upper middle segment, one of the reasons is that for the middle class' time is very limited to buy books. To prove it, this can be tracked to a group of the classes. 'Do they have the reference collection in their homes? Thus, publisher must think positive. That is, the middle group is not unwilling or uninterested, or because they only view and style hedonistic life-a mere world. However, they did not have time to buy books. Abdul Ghafar suggested to bring books to their houses, and we found that they never bargain how much it's discount. Therefore, Almahira is less interested in lower class segment, because they are many and tend to damage the market price. Books that are sometimes proven to be booming at a good price, are then flooded with similar books with cheaper prices and with more seemingly content, but in terms of price and character issues become corrupt and chaotic. The title and content become overlapping and the price is also chaotic [12]. Considering the growth of consumers, the readers of Islamic books are the upper middle class as targeted by the publisher. This indicates the existence of economic factors in the establishment of influence. The trend of the upper middle class is one indicator of the ability of the community to enjoy high economic growth that encourage their attitudes, interests and self-awareness to accept the sources of Islamic studies as the information needs to be met, although for this purpose publishers need experience and costs are very high. Nevertheless, the recognition of the ever-increasing sales of Islamic books shows that there has been an increase in Muslim interest in Islamic books. But this is not without the effort of publishers to find market opportunities, because they have worked hard to ensure the affectivity of editorial work carefully and accurately so easily accepted by the market. The publisher's wishes are in line with market demands.

\section{E. Presenting a Complete Integration of Product Design Concept as Priority.}

Almahira always arranges its book collection to be published done in a whole and comprehensive manner. This is as a principle taken in presenting new works of reference books. When publishing books that bring the feel of discourse or dissent on a particular subject or theme, it in the same place give a complete and comprehensive explanation. Thoroughly, itis meant to involve balanced views and discussions of all opposing parties or different opinions on a particular topic so that the questions are answered clearly. The reviews are presented in a comprehensive and detailed study consisting of arguments, historical and social facts that are authentic to answer the problem. Additionally, related to illustration, for example, the director of Almahira said that in term of illustration design it pays more attention to ethics, so why the images should be presented is based on a strong reason. For example, the story of Khulafaur Rasyidin Abu Bakar has long existed, but the publisher presents it differently with details of where Abu Bakar lived, what kind of house he had, when he traveled, where he stopped over, and etc., explained by A. Ghafar. The plan to publish a new book should be able to come up with a better packaging idea, both in terms of information presentation and physical appearance. The choice to issue a new title must be carefully thought so as to get the uniqueness of the product amid the collection that has been circulating in the market. Prior to production, the publisher must identify the needs of the segment of the community, either those that actually use these sources or those that potentially use planned products, and profit economically. It aims to realize the literacy idea through publications by looking at the information needs thoroughly with complete integration of design concept. So, readers will be proud of the uniqueness and have more interest in the reference book packaging. 
As a result, it is known that Almahira has succeeded in establishing the distinction and competitive advantage by creating the uniqueness of every book published. If the series of actions are integrated and done in five strategies, the conclusion can be drawn that if publishers are able to base their efforts on the five keys to success, they will remain successful in the very tight business competition. As a condition, the application of the concept must be a unified approach of a series of such corporate publishing actions, and are not implemented separately. Nevertheless, to some extent, there are still some approaches which are similar to other publishers' strategies. In short, these are distinctive results of the research compared to those conducted before. It is clear the improvement of managerial and administrative systems is a competitive strategy in the sales sector as applied in CV. Robbani Press [14]. This result is also different from the strategy adopted by Gramedia strengthening marketing aspect. The company TB Gramedia Ambassadors Plaza grows and builds strategies to deal with competitive "discount war", maximizes strategic location and limited space, creates independent creative promotions, and evaluates procurement systems with best-seller product procurement, and products that consumers need [15]. Differently, Evert's research reveals the main weakness of PT Pustaka Sinar Harapan lieson its production-oriented activities, not on the needs of consumers, so that all the advantages possessed cannot be utilized optimally [16]. So, this reported result can function as best practice which is brightly strengthened on strategy concentration of production process of consumers' needs that can be useful for other book publishers.

\section{CONCLUSION}

The business of publishing Islamic reference books has a bright prospect and is still wide open because this kind of reference book in Indonesia is still minimal. Such publishing business will remain successful and continue to grow if it is managed by applying strategic actions as conducted by Almahira which concentrate much more on production quality and process. These integrated actions include direct observation by implementing creativity and expertise in the identification of public information needs; enterprise product innovations, keeping open mind in competition and diversity; as well as creating uniqueness of the product by presenting a complete integration of product design concept as priority. The publisher also applies a rigorous pre-print editing process to obtain public perception and acceptability. Besides, setting to publish a collection of premium types for the upper middle segment is selected because the middle class religious awareness is on the rise. Now the publisher also faces severe obstacles with the growing use of internet. It is feared, people will leave the book just like that if the digital information and knowledge needed is easily accessible online. Optimistically, the internet does not answer all the needs of people, it is evidenced that many book publishers still exist, including Almahira. Publishers believe that the future public awareness of Islamic books is increasing, although reading interest does not increase significantly. As alternative solution, the strategic actions as being analyzed could help publishers to sustain and succeed.

Referring to the conclusion above, I can propose the following recommendation.

1. Islamic book publishers need more creative in creating a new book to enrich the treasures of a more contextual and innovative reference collection in line with technological developments, needs and interested issues. Publishers also need to do repositions by being more open to respond positively to the presence of digital books, multimedia and internet-based information sources because the presence of the internet has become part of lifestyle and the needs of modern society.

2. The government and related institutions have to cooperate with publishers to actively promote reading interest in order to increase people awareness in reading the sources of Islamic references. This can be done, for instance, by using various printed and electronic media such as television and radio. They also need collaboration to publish books with affordable price to accelerate literacy for lower class.

3. Other researchers have to develop research on related themes such as the role of publishers in the development of Islamic-based reference collection of electronic or digital materials and the effectiveness of its use for the user community. Further research is needed if the publisher of the next Islamic reference collection will prioritize publishing in digital or printed format. This is a bigger challenge for publishers.

\section{ACKNOWLEDGEMENT}

This research was supported by the Research Center of University of UIN Syarif Hidayatullah Jakarta within research project 2014.

\section{REFERENCES}

[1] F. R. David, Manajemen Strategi: Konsep (terjemahan), Jakarta: Salemba Empat, 2006.

[2] Boyd and Walker, Manajemen pemasaran: Suatu Pendekatan Strategis Dengan Orientasi Global. Jakarta: Penerbit Erlangga, 2000.

[3] P. Kothler, Manajemen pemasaran (terjemahan). Jakarta: PT. Indeks Kelompok Media, 2005.

[4] H. J. Handito, Strategi Kompetisi: Jangan Sekedar Menang Bersaing Rahasia Bisnis Orang Jepang. Published by Syafrizal Helmi. https:// shelmi. wordpress. com/2011/01/11/strategi-kompetisi/

[5] A. Mustofa, "Majalah al-Kusu". 09, 2014

[6] H. Patilima, Metode Penelitian Kualitatif. Bandung: ALfabeta, 2007.

[7] A. Ghafar, Direktur of Almahira Jakarta, 2014 (Interview).

[8] I. Kleden, Buku di Indonesia: Perspektif Ekonomi Politik Tentang Kebudayaan. Jakarta: Yayasan Obor, 1999.

[9] A. Taryadi, Buku dalam Indonesia Baru. Jakarta: Yayasan Obor Indonesia, 1999.

[10] A. Alamsyah, Analisis Strategi Bersaing dalam Meningkatkan Penjualan Pada CV. Robbani Press. Tesis, Universitas Guna Darma, 2011.

[11] M. Fitriandari, Analysis of Business Strategy at Gramedia Bookstore Duta Plaza in Denpasar City. Denpasar: Udayana University, 2015.

[12] E. L. Klavert. Analisis Daya Saing Industri Penerbitan Buku Dalam Penetapan Strategi Bersaing PT. Pustaka Sinar Harapan. Tesis, Universitas Indonesia. 